\title{
School Effect and Student Performance: a Latin American Assessment from PISA
}

\author{
Fabiana A. Alves ${ }^{\mathrm{a}}$, Osvaldo Candido ${ }^{\mathrm{b}, \mathrm{c}, \boldsymbol{w}}$ \\ ${ }^{a}$ Anísio Teixeira National Institute of Educational Studies and Research, Brazilian Ministry of Education, \\ Brasilia, DF, Brazil \\ $\bowtie$ fabianassis30@gmail.com \\ ${ }^{\mathrm{b}}$ Graduate School in Economics, Catholic University of Brasilia, Brasilia, DF, Brazil \\ ${ }^{\mathrm{c}}$ School of Economics and Management, University of Porto, Porto, Portugal \\ $\bowtie$ candido.f@gmail.com $\quad$ "Corresponding author
}

\begin{abstract}
Combining data from the last three editions of the Programme for International Student Assessment (PISA) with a multilevel approach, we aim to assess the effect of Latin American schools on student attainment and identify factors that contribute to their performance. It is found that family background, students' characteristics and school community profile (peer effect) are paramount in explaining student performance. Regarding the school facilities, the disciplinary climate in the classroom and the existence and adequacy of pedagogical resources are the determinants that stood out the most. Moreover, the use of a multilevel approach is of utmost importance, since a considerable part of student performance variation is explained by differences among schools (school effect). Finally, the peer effect and the school effect suggest that the socioeconomic inequality in Latin American countries is quite important in determining the students' performance.
\end{abstract}

Article History: Received: December 132019 / Revised: May 112020 / Accepted: November 182020 Keywords: Student attainment; Multilevel model; School effect; Peer effect

JEL Classification: C3; I2; O5

\section{Acknowledgements}

The authors gratefully acknowledge the financial support of Foundation for Research Support of the Federal District - Brazil (FAP-DF), grant numbers 193.000.217/2014 and 193.000.966/2015. The authors also thank to Gabriel Rodriguez (Editor-in-Chief), Ana Dammert (Associate Editor) and two anonymous referees for valuable comments. 


\section{Introduction}

The interest in assessing the students' performance and the educational system effectiveness began more than fifty years ago. At that time, the education data availability were quite scarce. Across the years, the Educational Effectiveness Research (EER) became a big scientific field in academic world. A lot of work has been done in order to understand the determinants not only of the students' performance but also the effectiviness of ecucational systems around the world. A complete review of the field can be found in Reynolds et al. (2014) and Lindorff et al. (2020).

Data from large-scale educational assessments, such as the Programme for International Student Assessment - PISA, are becoming increasingly important to understand economic, educational and social phenomena. PISA evaluates Reading, Scientific literacy, and Mathematics skills. In addition, it is common to apply contextual questionnaires that portray characteristics of students, families and schools. Assuming that student's performance is a good indicator for the educational system quality, and that data on families and schools are available, it is possible to identify some factors that explain students' cognitive abilities.

Several studies have highlighted the characteristics of the student and his/her family background as the main determinants of schooling success. Regarding the role of the school, there is no consensus. Coleman et al. (1966) was one of the first and most relevant studies on the subject that relates students' test results to assess verbal and nonverbal skills to the characteristics of the students, the families, the schools, and the teachers. They conclude that the differences in educational output would be better explained through socioeconomic variables than by school related characteristics. Subsequently, Hanushek et al. (1996), from a broad review of previous studies and new empirical analysis, conclude that articles that indicate a positive and significant relationship among school's characteristics and student's performance use data with such a high degree of aggregation that it eventually inflates the estimated coefficient. For studies in which data have low level of aggregation, evidence of any positive relationship among those characteristics and the student performance (if statistically significant) are much smaller. In contrast to these two studies, Hedges et al. (1994), Greenwald et al. (1996a,b) and Dewey et al. (2000) find significant effect of school related variables on student productivity.

Concerning Latin American countries, it can be seen some improvement of their educational indicators in the last decades. Mainly in the educational attainment. Such advances can be observed in the indicators related to "access to school". With increasing attendance and permanence of students in the educational system, these countries have been able to raise the average years of schooling of their population. Despite those breakthroughs, the cognitive skills of Latin American students participating in international testing remain far behind the skills of students from developed countries. Hanushek et al. (2012), by comparing six groups of countries (East Asia and India, Central Europe, Organisation for Economic Co-operation and Development (OECD), Latin America, the Middle East and North Africa, and Sub-Saharan Africa), show that the average performance of Latin American students is only slightly superior to that of sub-Saharan Africa. This suggests that policies for raising student's learning could be of great impact in this field. Another research with similar results is de Jorge-Moreno (2016).

\section{; PUCP}


These findings about Latin American countries seem consistent with their high inequality (as measured by Gini's coefficients), and low productivity, Gross Domestic Product (GDP) per capita, Human Development Index (HDI) among other economic and social indicators. If on the one hand cognitive abilities have a positive impact on GDP, on the other hand countries with low productive capacity have few resources devoted to education (Hanushek et al., 2008; Hanushek and Woessmann, 2012). As a solution to this vicious cycle, governments should optimize public expenditures in education, which depends on the correct identification of the most relevant factors for an efficient educational system.

As also noticead by Hanushek et al. (2008) and Hanushek and Woessmann (2012), the empirical debate warns that the use of years of schooling as a proxy for measuring human capital is quite fragile, since one year of schooling in different educational systems (Peru and Singapore, for example) can provide a distinct advantage in skills. They show that the cognitive abilities of the population are more strongly related to individual gains, income distribution and economic growth than to years of schooling. Thus, it is imperative not only to guarantee regular school access and permanence, but an educational system that provides higher quality in terms of learning.

Taking into account the aforementioned literature, and the empirical debate around assessing students' performance, the main objective of this work is to assess the determinants of the Latin American students' performance. The variables supposed to affect student's performance are grouped into three main dimensions: individual characteristics, family background, and school facilities. The data used for the empirical analysis comes from the last three available editions of PISA (2009, 2012 and 2015) for seven Latin American countries.

PISA is one of the most important international students assessment nowadays. It allows to measure not only students' knowledge and skills but also the students' individual and family characteristics, the school physical infrastructure and pedagogical resources availability, the teachers' profile, the students' and teachers' perceptions about school environment, management, etc. Additionally, several indicators are calculated and maintained by PISA consortium with the participating countries assistance, subsidizing decision-making and educational public policies design.

Mostly, PISA is representative for fifteen years old students from each participant countries, individually. Many of Latin American countries are included in some PISA editions, some as OECD members, and some as invited countries, but only Brazil, Chile, Colombia, Costa Rica, Mexico, Peru, and Uruguay participated on all 2009, 2012, and 2015 editions, which were included in this study. Even so, according to the 2018 World Economic Outlook database, by International Monetary Fund, these countries account for almost $70 \%$ of all Latin America population. Brazil, Mexico, and Colombia are the most populated countries, with more than $60 \%$ of Latin America population. In terms of GDP, these numbers are not quite different, $77 \%$ and $65 \%$ respectively, so leading to the most relevant part of the region, in many aspects.

Combined with PISA microdata, a multilevel approach is used to perform the empirical analysis. This method has become widely used as an empirical strategy when the data available have a hierarchical structure. That is, the observations have multiple levels of aggregation. 
An interesting feature of this modeling is the possibility to identify micro-level effects (from individual characteristics) and macro-level effects (from differences among aggregating groups). Because the educational data structure has mostly the aforementioned features, the multilevel approach is the recommended tool for dealing with PISA microdata (OECD, 2009) and the main approach used in the EER literature. See for instance Ho (2013), Hopfenbeck et al. (2018), and Yalcin (2017). For this work, two hierarchical levels are considered: student level and school level. Thus, the effects of students' characteristics and differences among schools (school effect) on the students' performance on PISA can be estimated.

In spite of multilevel be a well-known and well-stabilished approach, Hanchane and Mostafa (2012) warn that endogeneity bias may arise in estimating multilevel models for educational production functions and propose a robust methodology that allows to overcome them. The authors suggest that the main source of endogeneity comes from the subject level (school level), that is, when individuals explanatory variables included in the model are correlated with the school level random component due to an omitted variable problem. In this sense, their method consists of including the peer effect in the estimation of the multilevel model, i.e., include the students' characteristics aggregated by school. Using PISA 2003 data, the authors find a significant endogeneity for two out of three countries in the sample.

Another rationale in considering this peer effect is that behavior, as well as student performance, is also influenced by the socioeconomic statuses, and other characteristics of those individuals surrounding the student. That is, the cultural and socioeconomic status of the neighborhood or community (or their peers), to which the student belongs, is important in determining his behavior and academic performance. Caldas and Bankston (1997) and van Ewijk and Sleegers (2010) show some evidence of the importance of the inclusion of peer effects variables for student performance assessments. In our empirical analysis for all countries, the inclusion of this peer effect is statistically significant.

The main results point out that the socioeconomic status is the most important in determining the students' performance on PISA. This result is found not only in a cross countries comparison but also within each countries individually. It corroborates the literature that suggests that socioeconomic inequality is a very important issue that have the most relevant impact in the students' academic achievements. Besides, our results show that the school effect is, mainly, very high for Latin American countries and a big part of this effect is explained by the respective socioeconomic status of the school's community. It leads to the conclusion that exists a high socioeconomic segmentation on the analyzed educational systems. To some extent, the educational systems studied reproduce the inequalities that exist in society itself.

In this way, the Latin America governments should reinforce policies that improve schools and the environment surrounding them, consequently reducing the inequality in those countries. This could be done by allocating more financial resources and better qualified professionals to those schools that serve a socio-economically disadvantaged public, in order to overcome the existing inequalities in the educational system.

This paper is organized as follows. Section 2 is devoted to the methodological approach with a brief discussion of the Programme for International Student Assessment (PISA) and the

\section{PUCP}


indicators used to explain the observed variation in student performance. A description of the multilevel modeling technique is also presented in this section. The models set for each country and for each PISA edition, as well as a discussion on the research results can be found in section 3. Section 4 is dedicated to some closing comments.

\section{Data and Empirical Procedures}

The educational services provision, like other services in economics, results from the combination of production factors. The technology involved in this process can be very complex and subject to random shocks coming from educational policies, economic conditions and even political conflicts, which may affect the educational system quality in a country or region.

The concept of production function, which stems from fundamentals of Microeconomics, has been widely used in education since Coleman et al. (1966). An educational production function can be formulated as a combination of several factors that maximize the quality of the transmission of knowledge to students. This function can be expressed through a model that outlines the relationship between the educational inputs and the students' attainment (output). Therefore, indicators such as students' performance scores, years of schooling, literacy, grade repetition (academic year/course), success in the labor market, approval in selection processes, among others, can be used for this purpose.

Regarding inputs, one can explore several factors that can be grouped into three large dimensions:

i. Factors related to the individual (I): gender, age, interest or enthusiasm for the school and the subjects studied, time spent studying, interest in Reading and Information and Communication Technology (ICT), school dropout, etc.

ii. Factors related to the student's family background (B): economic conditions of the student's family, income or occupation of the parents, social stratum to which the family belongs, parental education, possession of household goods, structure and household situation, among others.

iii. Factors related to school facilities (S): physical infrastructure, existence of pedagogical resources such as teaching materials, reading rooms, libraries, computer and science laboratories, the student-to-teacher ratio, the educational level of the teachers, the commitment and dedication of the employees, the autonomy to manage the human and financial resources, etc.

In this way, an educational production function can generically be represented as

$$
R=f(I, B, S)
$$

where $R$, a student's performance measurement, is a function of student related factors: individual (I), family background (B) and school facilities (S). 


\subsection{PISA Assessment Data}

The Programme for International Student Assessment (PISA) is a large-scale educational evaluation coordinated by the Organization for Economic Co-operation and Development (OECD), held every three years since 2000. The population target is defined as 15-year-old students near the end of their compulsory education.

The assessment focuses on three cognitive areas: Science, Mathematics, and Reading. Within each edition, special focus is placed on one of the areas. Reading was highlighted in the first edition in 2000 and again in 2009. In the 2003 and 2012 editions focus was placed on Mathematics and, in 2006 and 2015, the focus was on Sciences. In addition to the tests that assess students' proficiency, context questionnaires are applied bringing aspects related to the student, the family, and the school. These questionnaires are used in the formulation of demographic, social, and educational indicators that can be used towards a better understanding of the differences in performance among students.

For this work, the data for Latin American students in three editions of PISA are used: 2009, 2012 and 2015. In 2009, ten out of twenty Latin American countries engaged on PISA (Argentina, Brazil, Chile, Colombia, Costa Rica, Mexico, Panama, Peru, Trinidad \& Tobago, and Uruguay); in 2012, eight out of twenty (Argentina, Brazil, Chile, Colombia, Costa Rica, Mexico, Peru and Uruguay), and in 2015 ten out of twenty (Argentina, Brazil, Chile, Colombia, Costa Rica, Dominican Republic, Mexico, Peru, Trinidad \& Tobago e Uruguay) engaged on PISA. However, only Brazil, Chile, Colombia, Costa Rica, Mexico, Peru, and Uruguay participated in all three editions with representative samples. ${ }^{1}$ For this reason, the empirical analysis is focused on these countries. Additionally, since some indicators are available only for the area focused in the given edition, only these data are used, i.e, in 2009, Reading; in 2012, Mathematics; and in 2015, Science.

In order to assess the students' performance, five indicators based on the student's questionnaire are used. ${ }^{2}$ They represent student characteristics, family background and the student's perception of the disciplinary climate in the classroom. Additionally, school facility indicators, extracted from the questionnaire answered by the school principal (or someone nominated by him), are included. A summary of these indicators can be seen in Table 1.

The ESCS indicator is built on information about schooling and parental occupation, household goods, and educational and cultural resources. It is one of the most used proxy for the family background. The REPEAT, AGE, and FEMALE variables refer to student characteristics. REPEAT is considered a proxy for student performance in prior periods.

Concerning school facility variables, the indicators are: availability of pedagogical resources (SCMATEDU and SCIERES), disciplinary climate in the classroom (DISCLIMA and DISCLISCI),

\footnotetext{
${ }^{1}$ Panama, Dominican Republic, and Trinidad \& Tobago were not in all PISA editions. Argentina has appeared in all editions, however, in 2015 the sample was drastically reduced and became not representative for the country. It was decided to keep in the empirical analysis only the countries with representative sample in the aforementioned three PISA editions.

${ }^{2}$ Several other indicators were used, but most of them were not available for the entire sample. Thus, their inclusion reduced dramatically the sample size and others were not statistically significant. These indicators were excluded from the analysis and will not be reported, but are available upon request.
}

\section{PUCP}


Table 1

Summary of selected PISA indicators.

\begin{tabular}{|c|c|c|c|}
\hline Indicator & Description & Year & Dimension \\
\hline ESCS & Index of economic, social and cultural status & $2009 / 2012 / 2015$ & Family \\
\hline AGE & Age of student & $2009 / 2012 / 2015$ & \\
\hline FEMALE & Gender: (1) Female (0) Male & $2009 / 2012 / 2015$ & Student \\
\hline REPEAT & $\begin{array}{l}\text { Dummy variable that indicates student } \\
\text { grade retention }\end{array}$ & $2009 / 2012 / 2015$ & \\
\hline DISCLIMA & $\begin{array}{l}\text { Perception of the student about the } \\
\text { disciplinary climate in the classroom }\end{array}$ & $2009 / 2012$ & \\
\hline DISCLISCI & $\begin{array}{l}\text { Perception of the student about the } \\
\text { disciplinary climate in the science classes }\end{array}$ & 2015 & \\
\hline STRATIO & $\begin{array}{l}\text { Ratio between the number of students and } \\
\text { teachers in the school }\end{array}$ & $2009 / 2012 / 2015$ & \\
\hline SCMATEDU & Educational Resources Index & $2009 / 2012$ & School \\
\hline SCIERES & Resources availability index for Sciences & 2015 & \\
\hline RESPRES & School autonomy index for resource allocation & $2009 / 2012 / 2015$ & \\
\hline PROPQUAL & Percentage of teachers with higher education & $2009 / 2012$ & \\
\hline PROAT5AM & Percentage of teachers with MSc. & 2015 & \\
\hline TCSHORT & Index on the teacher deficit & $2009 / 2012$ & \\
\hline STAFFSHORT & Index on the deficit of teachers and assistants & 2015 & \\
\hline
\end{tabular}

student-to-teacher ratio (STRATIO), teachers' educational degree (PROPQUAL and PROAT5M), teacher and teaching staff shortage (TCSHORT and STAFFSHORT), and institutional autonomy regarding resource allocation (RESPRES).

Additionally, averaged (by school) versions of REPEAT and ESCS variables (MESCS and MREPEAT) are included in the model. The rationale is twofold: to evaluate the peer effect concerning to socioeconomic status of the school (or community profile surrounding the school) and to solve endogeneity problems. The latter will be discussed further.

The sample used in the empirical analysis comprises the indicators summarized in Table 1 for seven Latin American countries - Brazil, Chile, Colombia, Costa Rica, Mexico, Peru, and Uruguay - that engaged on the PISA assessment in 2009, 2012 and 2015. These indicators were kept in its original scale. Thus, for more details about the computing, interpretation and scales of them, the reading of the PISA Technical Reports is recommended.

It is worth to notice that Latin American countries have a lot of differences when compared to OECD countries, when it comes to educational aspects. For example, the share of children around 15-year-old (usually at upper secondary school) out-of-school in most Latin American countries is very high comparatively to OECD an EU23 averages. The out-of-school rate at populous Latin American countries used in this study like Brazil (14.8\%), Colombia (21.0\%), and Mexico (26.1\%) figure above OECD (7.7\%) and EU23 (5.5\%) rates, although Chile's rate $(4.6 \%)$ is remarkably smaller than its regional peers. Figure 1 illustrates those differences.

Many authors relate disadvantage indicators such as dropout, repetition and out-of-school rate to the socioeconomic inequality. That is, countries with higher values on disadvantage indicators 


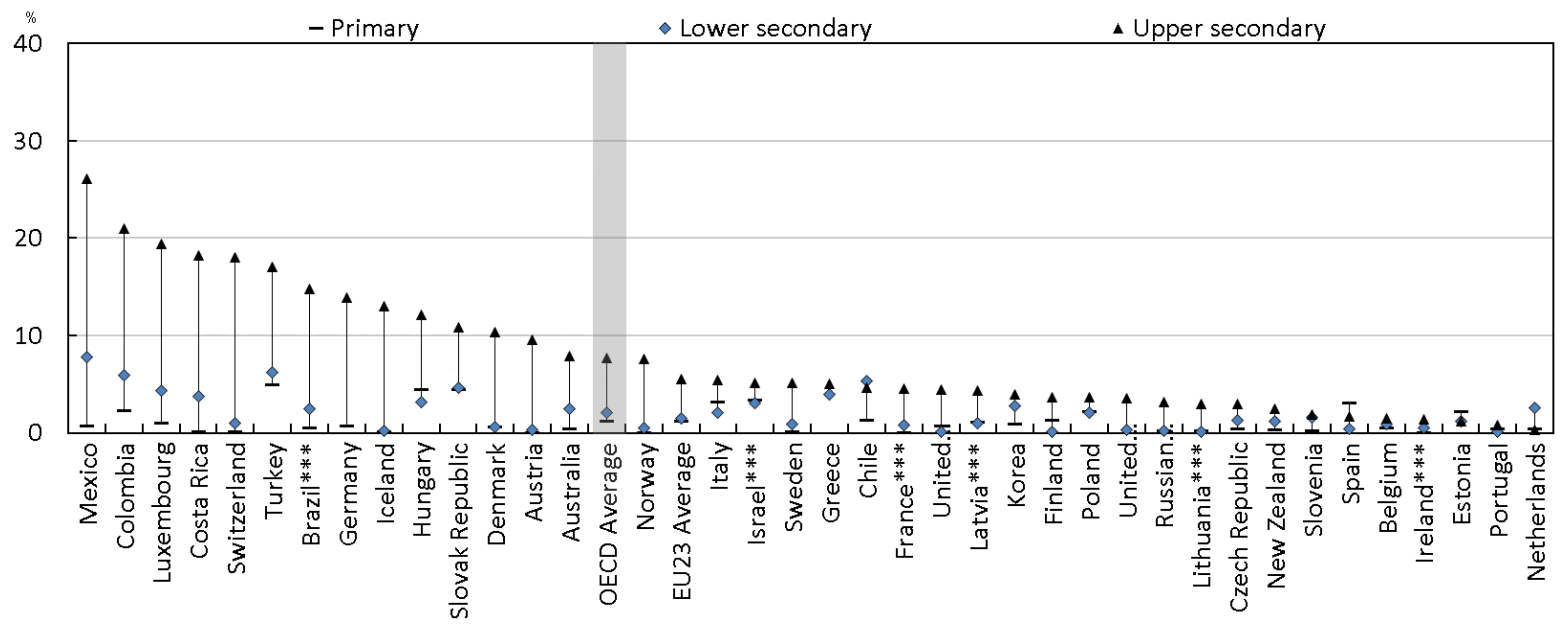

Source: OECD (2020).

Note: The official data sources for this indicator are the UOE data collection for enrolment data and the United Nations Population Division (UNPD) for population data. See Source section and Annex 3 in OECD (2020) for more information and notes.

*** The source for population data is the UOE data collection for demographic data (Eurostat/DEM) instead of the United Nations Population Division (UNPD).

Figure 1. Out-of-school rate, by level of education (2018)

also have higher socioeconomic inequality. The ESCS indicator is created standardizing the OECD student's mean as zero and computing the values for each country and each aggregation, taking this as reference. Figure 2 shows the ESCS values for the countries included in this study, aggregated by the occurrence or not of student retention at some point of his/her school's trajectory (given by the variable REPEAT). It can be seen that for all the selected countries the ESCS aggregated value is negative and relatively far from zero, with a worse situation for students with at least one grade retention (REPEAT $=1$ ) in all three PISA editions considered.

\subsection{Multilevel Models}

Multilevel or hierarchical models are suitable for analyzing data that present a hierarchical or nested structure (i.e., individuals or groups are ranked or aggregated by location, status, authority, etc.). In most large-scale educational assessments, this structure is observed, since students are allocated to classes and classes are organized in schools.

For Rasbash et al. (2017), the use of Multiple Regression (OLS) models on hierarchical data is inadequate because it does not quantify the variation between the classes and the schools. The multilevel analysis improves the accuracy of the estimators related to individuals, allowing the researcher to better understand the effects of the hierarchy and to elaborate more complex questions. In addition, it prevents underestimation of the coefficients standard errors, since it takes into account other source of variations.

From the PISA data, it can be identified two hierarchical levels — student and school — which allow us to represent the model as follows 


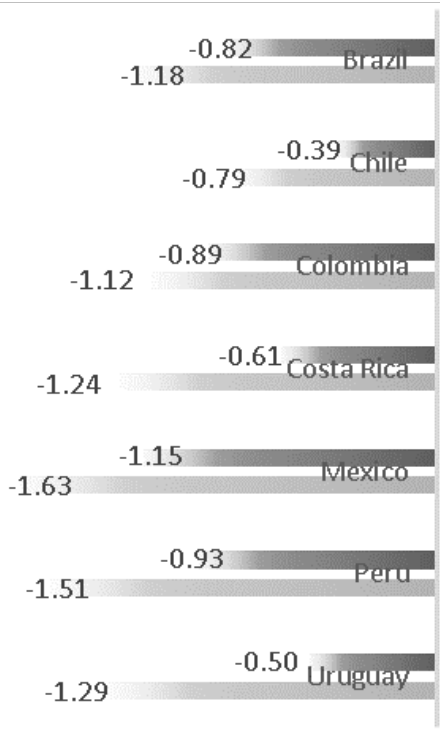

2015

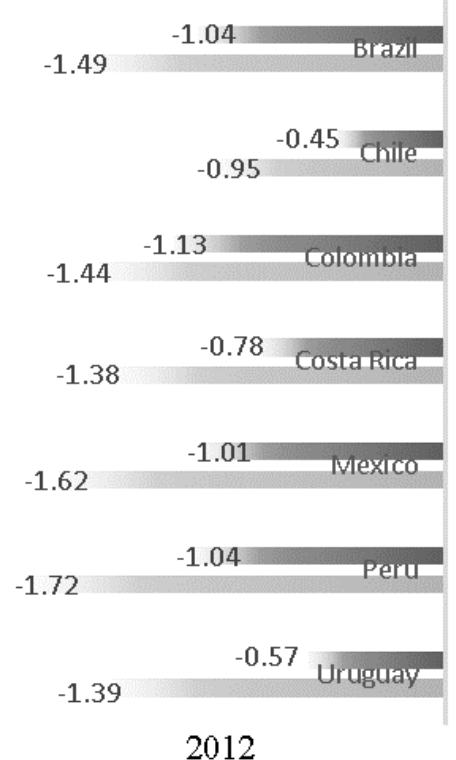

2012

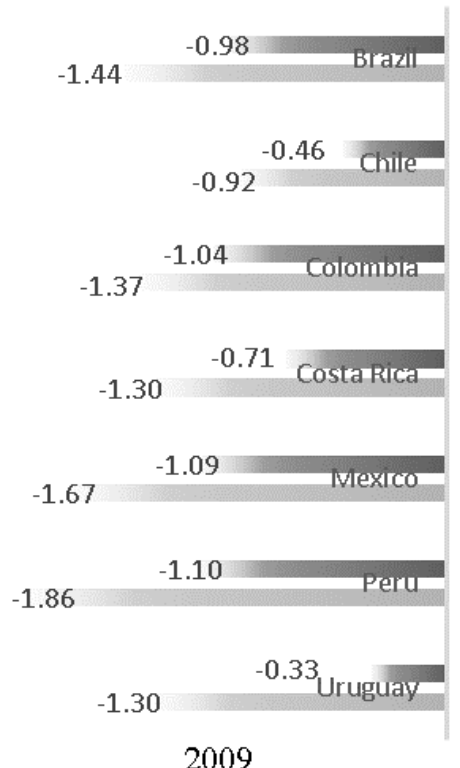

2009

Source: OECD $(2012,2014,2017)$. The darker gray stands for no grade retention $($ REPEAT $=0$ ).

Figure 2. Index of economic, social and cultural status (ESCS): 2015, 2012 and 2009, by grade retention (REPEAT).

Level 1 - Student

Level 2 - School

$$
\begin{gathered}
y_{i j}=\boldsymbol{\beta}_{0 j}+\beta X_{i j}+\varepsilon_{i j} \\
\boldsymbol{\beta}_{0 j}=c+\gamma K_{j}+\delta \bar{X}_{\cdot j}+v_{j}, \quad \text { or } \\
y_{i j}=c+\beta X_{i j}+\gamma K_{j}+\delta \bar{X}_{\cdot j}+v_{j}+\varepsilon_{i j}
\end{gathered}
$$

where $y_{i j}$ is the score on PISA (Science, Mathematics or Reading) of the student $i$ from school $j ; X_{i j}$ are the student $i$ from school $j$ variables; $\bar{X}_{\cdot j}$ is the peer effect variables, i.e., students' family background and individual characteristics averaged by school; $K_{j}$ school $j$ variables, and $\varepsilon_{i j}$ and $v_{j}$ are random components related to the measurement level (Level 1 - Student) and the subject level (Level 2 - School), respectively. The main difference between the specification in 1 and the Multiple Regression is the presence of these two random components. The intercept $c$ is the same for all students and schools. All these variables are summarized in Section 2.1.

The standard hypotheses to make inference from 1 are:

1. The random components are uncorrelated and both independent and normally distributed

$$
\left(\begin{array}{l}
\varepsilon \\
v
\end{array}\right) \stackrel{\text { i.i.d. }}{\sim} \mathcal{N}\left(\left(\begin{array}{l}
0 \\
0
\end{array}\right),\left(\begin{array}{cc}
\sigma_{\varepsilon}^{2} & 0 \\
0 & \sigma_{v}^{2}
\end{array}\right)\right) .
$$

2. The random components are uncorrelated with the explanatory variables, i.e., for $Z=[X K \bar{X}]$ and $\epsilon=[\varepsilon v], \operatorname{cov}(Z, \epsilon)=\mathbf{0}$. 
From the hypotheses above and considering $\mathbf{Z}=\left[\begin{array}{llll}\mathbf{1} & X & K & \bar{X}\end{array}\right], \boldsymbol{\theta}=\left[\begin{array}{ccc}c & \beta & \gamma\end{array}\right]^{\prime}, \boldsymbol{\sigma}=\left[\begin{array}{ll}\sigma_{\varepsilon}^{2} & \sigma_{v}^{2}\end{array}\right]$ and $\mathbf{V}=\operatorname{var}(\mathbf{y})$, the $\log$-likelihood function for estimating the parameters of the equation 1 can be represented as follows

$$
\ell(\boldsymbol{\theta}, \boldsymbol{\sigma} \mid \mathbf{y}, \mathbf{Z}) \propto \frac{1}{2}\left\{\log |V(\boldsymbol{\sigma})|+(\mathbf{y}-\mathbf{Z} \boldsymbol{\theta})^{\prime}(V(\boldsymbol{\sigma}))^{-1}(\mathbf{y}-\mathbf{Z} \boldsymbol{\theta})\right\} .
$$

Thus, the Restrict Maximum Likelihood Estimator (RMLE) is

$$
(\hat{\boldsymbol{\theta}}, \hat{\boldsymbol{\sigma}})=\underset{\boldsymbol{\theta}, \boldsymbol{\sigma}}{\operatorname{argmax}} \ell(\boldsymbol{\theta}, \boldsymbol{\sigma} \mid \mathbf{y}, \mathbf{Z}) .^{3}
$$

If the hypothesis 2 does not hold for at least one explanatory variable, the endogeneity problem arises. According to Hanchane and Mostafa (2012), when modeling student performance determinants, the researcher has to take into account for the endogeneity that comes from school level. The authors argue that this problem arises from the possible correlation among students' individual characteristics and omitted school related variables. To deal with this, the authors suggest the inclusion of the so-called "peer effect". The rationale is to proxy the school community profile, which is considered relevant in determining the school performance according to findings in the literature. This justify the inclusion of the variables in $\bar{X}$.

It is worthy to notice that in the model individuals (students) of different groups (schools) are independent and students within the same schools share the same $v_{j}$, thus correlated. Therefore, since the variance of $y_{i j}$ is $\mathbf{V}=\operatorname{var}\left(v_{j}\right)+\operatorname{var}\left(\varepsilon_{i j}\right)$ and the covariance between two students $i$ and $i^{\prime}\left(i \neq i^{\prime}\right)$ in the school $j$ is $\operatorname{cov}\left(y_{i j}, y_{i^{\prime} j}\right)=\operatorname{var}\left(v_{j}\right)=\sigma_{v}^{2}$, the correlation between two students from the same school is

$$
\rho=\frac{\sigma_{v}^{2}}{\sigma_{v}^{2}+\sigma_{\varepsilon}^{2}} .
$$

This allows one to evaluate between-school and within-school effects. In other words, it is possible to identify the school effect on the student performance measure, i.e., the higher is $\rho$ the higher is the impact of the difference among the schools on the student performance. ${ }^{4}$ The reason is that $\rho$ (also referred to as intraclass correlation) indicates the fraction of the students' performance variance explained by the grouping structure in the population.

\section{Results}

Tables 2 to 5 show the main results for the empirical analysis. Tables 2 to 4 show the parameter estimates for the specification in 1, with and without peer effect (including and excluding the vector of variables $\bar{X}$ ), for each country and PISA edition under analysis. Table 5 shows the variance decomposition, i.e., between-school, within-school and overall. On this table it is also included results for a benchmark model which is merely a null model (only a constant is included in the model).

\footnotetext{
${ }^{3}$ For details on parameter estimation of multilevel models see De Leeuw et al. (2008).

${ }^{4}$ Note that $\rho \neq 0$ implies the Ordinary Least Squares (OLS) estimator for 1 is biased and inconsistent.
} 
Table 2

Estimation results - PISA 2009 (Reading).

\begin{tabular}{|c|c|c|c|c|c|c|c|c|c|c|c|c|c|c|}
\hline \multirow{2}{*}{ Variables } & \multicolumn{2}{|c|}{ Brazil } & \multicolumn{2}{|c|}{ Chile } & \multicolumn{2}{|c|}{ Colombia } & \multicolumn{2}{|c|}{ Costa Rica } & \multicolumn{2}{|c|}{ Mexico } & \multicolumn{2}{|c|}{ Peru } & \multicolumn{2}{|c|}{ Uruguay } \\
\hline & w/o p.e. & w/ p.e. & w/o p.e. & w/ p.e. & w/o p.e. & w/ p.e. & w/o p.e. & w/ p.e. & w/o p.e. & w/ p.e. & w/o p.e. & w/ p.e. & w/o p.e. & w/ p.e. \\
\hline ESCS & $\begin{array}{l}6.869^{* * *} \\
(0.602)\end{array}$ & $\begin{array}{l}5.460^{* * *} \\
(0.615)\end{array}$ & $\begin{array}{l}10.40^{* * *} \\
(1.261)\end{array}$ & $\begin{array}{l}8.093^{* * *} \\
(1.308)\end{array}$ & $\begin{array}{l}11.27^{* * *} \\
(0.814)\end{array}$ & $\begin{array}{l}9.340^{* * *} \\
(0.833)\end{array}$ & $\begin{array}{l}9.739^{* * *} \\
(0.922)\end{array}$ & $\begin{array}{l}8.553^{* * *} \\
(0.940)\end{array}$ & $\begin{array}{l}7.904^{* * *} \\
(0.362)\end{array}$ & $\begin{array}{l}6.650^{* * *} \\
(0.369)\end{array}$ & $\begin{array}{l}11.96^{* * *} \\
(0.983)\end{array}$ & $\begin{array}{l}9.970^{* * *} \\
(1.005)\end{array}$ & $\begin{array}{l}15.18^{* * *} \\
(1.121)\end{array}$ & $\begin{array}{l}13.69^{* * *} \\
(1.144)\end{array}$ \\
\hline AGE & $\begin{array}{l}9.708^{* * *} \\
(2.142)\end{array}$ & $\begin{array}{l}8.676^{* * *} \\
(2.139)\end{array}$ & $\begin{array}{l}10.81^{* * *} \\
(3.769)\end{array}$ & $\begin{array}{l}10.00^{* * *} \\
(3.760)\end{array}$ & $\begin{array}{l}11.33^{* * *} \\
(2.900)\end{array}$ & $\begin{array}{l}11.16^{* * *} \\
(2.887)\end{array}$ & $\begin{array}{l}16.52^{* * *} \\
(3.574)\end{array}$ & $\begin{array}{l}16.14^{* * *} \\
(3.565)\end{array}$ & $\begin{array}{l}0.666 \\
(1.449)\end{array}$ & $\begin{array}{l}-1.635 \\
(1.454)\end{array}$ & $\begin{array}{l}7.284^{* *} \\
(3.078)\end{array}$ & $\begin{array}{l}6.889^{* *} \\
(3.071)\end{array}$ & $\begin{array}{l}13.50^{* * *} \\
(3.949)\end{array}$ & $\begin{array}{l}12.87^{* * *} \\
(3.943)\end{array}$ \\
\hline FEMALE & $\begin{array}{l}22.78^{* * *} \\
(1.211)\end{array}$ & $\begin{array}{l}22.68^{* * *} \\
(1.209)\end{array}$ & $\begin{array}{l}15.80^{* * *} \\
(2.329)\end{array}$ & $\begin{array}{l}15.23^{* * *} \\
(2.305)\end{array}$ & $\begin{array}{l}7.675^{* * *} \\
(1.688)\end{array}$ & $\begin{array}{l}7.126^{* * *} \\
(1.675)\end{array}$ & $\begin{array}{l}9.876^{* * *} \\
(1.961)\end{array}$ & $\begin{array}{l}9.765^{* * *} \\
(1.959)\end{array}$ & $\begin{array}{l}14.79^{* * *} \\
(0.740)\end{array}$ & $\begin{array}{l}14.67^{* * *} \\
(0.739)\end{array}$ & $\begin{array}{l}7.876^{* * *} \\
(1.923)\end{array}$ & $\begin{array}{l}7.853^{* * *} \\
(1.910)\end{array}$ & $\begin{array}{l}29.78^{* * *} \\
(2.219)\end{array}$ & $\begin{array}{l}29.47^{* * *} \\
(2.215)\end{array}$ \\
\hline REPEAT & $\begin{array}{l}-43.24^{* * *} \\
(1.338)\end{array}$ & $\begin{array}{l}-40.70^{* * *} \\
(1.363)\end{array}$ & $\begin{array}{l}-47.11^{* * *} \\
(2.774)\end{array}$ & $\begin{array}{l}-43.65^{* * *} \\
(2.818)\end{array}$ & $\begin{array}{l}-42.83^{* * *} \\
(1.781)\end{array}$ & $\begin{array}{l}-41.89^{* * *} \\
(1.792)\end{array}$ & $\begin{array}{l}-47.57^{* * *} \\
(2.225)\end{array}$ & $\begin{array}{l}-46.07^{* * *} \\
(2.249)\end{array}$ & $\begin{array}{l}-42.30^{* * *} \\
(1.389)\end{array}$ & $\begin{array}{l}-37.33^{* * *} \\
(1.446)\end{array}$ & $\begin{array}{l}-39.13^{* * *} \\
(2.175)\end{array}$ & $\begin{array}{l}-37.71^{* * *} \\
(2.191)\end{array}$ & $\begin{array}{l}-63.37^{* * *} \\
(3.072)\end{array}$ & $\begin{array}{l}-57.62^{* * *} \\
(3.320)\end{array}$ \\
\hline DISCLIMA & $\begin{array}{l}4.835^{* * *} \\
(0.728)\end{array}$ & $\begin{array}{l}5.030^{* * *} \\
(0.725)\end{array}$ & $\begin{array}{l}2.272^{*} \\
(1.259)\end{array}$ & $\begin{array}{l}2.488^{* *} \\
(1.247)\end{array}$ & $\begin{array}{l}9.290^{* * *} \\
(1.048)\end{array}$ & $\begin{array}{l}9.206^{* * *} \\
(1.041)\end{array}$ & $\begin{array}{l}3.501^{* * *} \\
(1.148)\end{array}$ & $\begin{array}{l}3.304^{* * *} \\
(1.143)\end{array}$ & $\begin{array}{l}4.323^{* * *} \\
(0.455)\end{array}$ & $\begin{array}{l}4.425^{* * *} \\
(0.454)\end{array}$ & $\begin{array}{l}12.47^{* * *} \\
(1.187)\end{array}$ & $\begin{array}{l}12.51^{* * *} \\
(1.183)\end{array}$ & $\begin{array}{l}2.367^{* *} \\
(1.142)\end{array}$ & $\begin{array}{l}2.409^{* *} \\
(1.136)\end{array}$ \\
\hline PROPQUAL & $\begin{array}{l}1.813 \\
(8.373)\end{array}$ & $\begin{array}{l}-9.951 \\
(7.096)\end{array}$ & $\begin{array}{l}52.91^{*} \\
(27.65)\end{array}$ & $\begin{array}{l}17.16 \\
(20.31)\end{array}$ & $\begin{array}{l}-0.0331 \\
(9.707)\end{array}$ & $\begin{array}{l}-7.496 \\
(7.134)\end{array}$ & $\begin{array}{l}8.550 \\
(8.475)\end{array}$ & $\begin{array}{l}5.634 \\
(7.020)\end{array}$ & $\begin{array}{l}6.837 \\
(5.655)\end{array}$ & $\begin{array}{l}6.548 \\
(4.540)\end{array}$ & $\begin{array}{l}45.71^{* * *} \\
(10.43)\end{array}$ & $\begin{array}{l}10.81 \\
(8.318)\end{array}$ & $\begin{array}{l}31.51 \\
(36.10)\end{array}$ & $\begin{array}{l}-5.626 \\
(30.89)\end{array}$ \\
\hline TCSHORT & $\begin{array}{l}-3.494^{*} \\
(1.865)\end{array}$ & $\begin{array}{l}-0.159 \\
(1.617)\end{array}$ & $\begin{array}{l}1.590 \\
(3.262)\end{array}$ & $\begin{array}{l}2.800 \\
(2.318)\end{array}$ & $\begin{array}{l}-3.488 \\
(2.516)\end{array}$ & $\begin{array}{l}-2.457 \\
(1.832)\end{array}$ & $\begin{array}{l}-4.332 \\
(3.276)\end{array}$ & $\begin{array}{l}-2.868 \\
(2.729)\end{array}$ & $\begin{array}{l}2.249 \\
(1.434)\end{array}$ & $\begin{array}{l}0.0866 \\
(1.159)\end{array}$ & $\begin{array}{l}-4.024 \\
(3.296)\end{array}$ & $\begin{array}{l}-3.010 \\
(2.490)\end{array}$ & $\begin{array}{l}-1.123 \\
(2.939)\end{array}$ & $\begin{array}{l}0.127 \\
(2.514)\end{array}$ \\
\hline STRATIO & $\begin{array}{l}-0.224^{*} \\
(0.117)\end{array}$ & $\begin{array}{l}-0.179^{*} \\
(0.0990)\end{array}$ & $\begin{array}{l}0.257 \\
(0.389)\end{array}$ & $\begin{array}{l}0.236 \\
(0.286)\end{array}$ & $\begin{array}{l}-0.207 \\
(0.267)\end{array}$ & $\begin{array}{l}0.0399 \\
(0.197)\end{array}$ & $\begin{array}{l}0.678 \\
(0.414)\end{array}$ & $\begin{array}{l}0.512 \\
(0.350)\end{array}$ & $\begin{array}{l}0.247^{* * *} \\
(0.0543)\end{array}$ & $\begin{array}{l}0.0831^{*} \\
(0.0440)\end{array}$ & $\begin{array}{l}0.703^{* *} \\
(0.339)\end{array}$ & $\begin{array}{l}0.435^{*} \\
(0.257)\end{array}$ & $\begin{array}{l}0.447 \\
(0.404)\end{array}$ & $\begin{array}{l}0.666^{*} \\
(0.344)\end{array}$ \\
\hline SCMATEDU & $\begin{array}{l}10.90^{* * *} \\
(1.962)\end{array}$ & $\begin{array}{l}7.269^{* * *} \\
(1.663)\end{array}$ & $\begin{array}{l}8.694^{* * *} \\
(3.044)\end{array}$ & $\begin{array}{l}2.311 \\
(2.232)\end{array}$ & $\begin{array}{l}11.20^{* * *} \\
(2.419)\end{array}$ & $\begin{array}{l}3.798^{* *} \\
(1.834)\end{array}$ & $\begin{array}{l}9.982^{* * *} \\
(2.482)\end{array}$ & $\begin{array}{l}4.307^{* *} \\
(2.158)\end{array}$ & $\begin{array}{l}15.35^{* * *} \\
(1.328)\end{array}$ & $\begin{array}{l}3.650^{* * *} \\
(1.177)\end{array}$ & $\begin{array}{l}17.34^{* * *} \\
(2.766)\end{array}$ & $\begin{array}{l}7.482^{* * *} \\
(2.229)\end{array}$ & $\begin{array}{l}2.828 \\
(2.708)\end{array}$ & $\begin{array}{l}1.344 \\
(2.312)\end{array}$ \\
\hline RESPRES & $\begin{array}{l}23.96 * * * \\
(2.865)\end{array}$ & $\begin{array}{l}5.447^{* *} \\
(2.710)\end{array}$ & $\begin{array}{l}9.329 * * * \\
(3.022)\end{array}$ & $\begin{array}{l}1.904 \\
(2.213)\end{array}$ & $\begin{array}{l}11.70^{* * *} \\
(2.741)\end{array}$ & $\begin{array}{l}-5.416^{* *} \\
(2.326)\end{array}$ & $\begin{array}{l}8.472^{*} \\
(4.373)\end{array}$ & $\begin{array}{l}-4.977 \\
(4.238)\end{array}$ & $\begin{array}{l}10.07^{* * *} \\
(1.767)\end{array}$ & $\begin{array}{l}-2.199 \\
(1.520)\end{array}$ & $\begin{array}{l}9.398^{* * *} \\
(2.721)\end{array}$ & $\begin{array}{l}-2.882 \\
(2.267)\end{array}$ & $\begin{array}{l}27.10^{* * *} \\
(4.639)\end{array}$ & $\begin{array}{l}1.345 \\
(5.223)\end{array}$ \\
\hline MESCS & & $\begin{array}{l}27.36^{* * *} \\
(2.625)\end{array}$ & & $\begin{array}{l}23.43^{* * *} \\
(3.763)\end{array}$ & & $\begin{array}{l}40.06^{* * *} \\
(3.184)\end{array}$ & & $\begin{array}{l}23.75^{* * *} \\
(4.290)\end{array}$ & & $\begin{array}{l}27.90^{* * *} \\
(1.546)\end{array}$ & & $\begin{array}{l}40.35^{* * *} \\
(4.193)\end{array}$ & & $\begin{array}{l}31.12^{* * *} \\
(5.327)\end{array}$ \\
\hline MREPEAT & & $\begin{array}{l}-50.06^{* * *} \\
(6.250)\end{array}$ & & $\begin{array}{l}-79.61^{* * *} \\
(12.44)\end{array}$ & & $\begin{array}{l}-15.72 \\
(11.98)\end{array}$ & & $\begin{array}{l}-36.14^{* * * *} \\
(13.18)\end{array}$ & & $\begin{array}{l}-48.27^{* * *} \\
(4.558)\end{array}$ & & $\begin{array}{l}-30.78^{* *} \\
(14.65)\end{array}$ & & $\begin{array}{l}-11.77 \\
(8.561)\end{array}$ \\
\hline${ }_{-}^{\mathrm{cons}}$ & $\begin{array}{l}291.6^{* * *} \\
(34.96)\end{array}$ & $\begin{array}{l}358.0^{* * *} \\
(34.89)\end{array}$ & $\begin{array}{l}227.7^{* * *} \\
(65.41)\end{array}$ & $\begin{array}{l}307.6^{* * *} \\
(62.73)\end{array}$ & $\begin{array}{l}285.3^{* * *} \\
(47.19)\end{array}$ & $\begin{array}{l}320.4^{* * *} \\
(46.63)\end{array}$ & $\begin{array}{l}203.0^{* * *} \\
(57.06)\end{array}$ & $\begin{array}{l}233.8^{* * *} \\
(56.84)\end{array}$ & $\begin{array}{l}427.2^{* * *} \\
(23.42)\end{array}$ & $\begin{array}{l}495.7^{* * *} \\
(23.41)\end{array}$ & $\begin{array}{l}264.4^{* * *} \\
(49.31)\end{array}$ & $\begin{array}{l}338.6^{* * *} \\
(49.28)\end{array}$ & $\begin{array}{l}231.1^{* * *} \\
(63.02)\end{array}$ & $\begin{array}{l}254.7^{* * *} \\
(62.90)\end{array}$ \\
\hline $\mathrm{N}$ & 11741 & 11741 & 3293 & 3293 & 6730 & 6730 & 3453 & 3453 & 25751 & 25751 & 5269 & 5269 & 4222 & 4222 \\
\hline AIC & 131838.2 & 131639.5 & 36574.2 & 36491.3 & 75643.6 & 75491.6 & 37950.9 & 37899.6 & 284303.6 & 283862.7 & 59206.6 & 59089.6 & 48075.0 & 48022.5 \\
\hline BIC & 131934.0 & 131750.1 & 36653.5 & 36582.7 & 75732.2 & 75593.8 & 38030.8 & 37991.8 & 284409.6 & 283985.0 & 59292.0 & 59188.2 & 48157.5 & 48117.7 \\
\hline LR & $20 s$ & 9.8 & 94 & 4.0 & 16 & 3.0 & 64 & 4.6 & & 9.8 & & 9.2 & 65 & .6 \\
\hline
\end{tabular}

Notes: Robust standard errors between brackets. w/o p.e. and w/ p.e. stand for without and with peer effect, respectively. ${ }^{*} p<0.1,{ }^{* *} p<0.05,{ }^{* * *} p<0.01$.

$\mathrm{N}=$ Number of observations, $\mathrm{AIC}=$ Akaike Information Criterion, BIC $=$ Bayesian Information Criterion, and LR $=$ Log-likelihood Ratio $\chi^{2}$ statistic. 
Table 3

Estimation results - PISA 2012 (Mathematics).

\begin{tabular}{|c|c|c|c|c|c|c|c|c|c|c|c|c|c|c|}
\hline \multirow{2}{*}{ Variables } & \multicolumn{2}{|c|}{ Brazil } & \multicolumn{2}{|c|}{ Chile } & \multicolumn{2}{|c|}{ Colombia } & \multicolumn{2}{|c|}{ Costa Rica } & \multicolumn{2}{|c|}{ Mexico } & \multicolumn{2}{|c|}{ Peru } & \multicolumn{2}{|c|}{ Uruguay } \\
\hline & w/o p.e. & w/ p.e. & w/o p.e. & w/ p.e. & w/o p.e. & w/ p.e. & w/o p.e. & w/ p.e. & w/o p.e. & w/ p.e. & w/o p.e. & w/ p.e. & w/o p.e. & w/ p.e. \\
\hline \multirow[t]{2}{*}{ ESCS } & $7.453^{* * *}$ & $6.077^{* * *}$ & $12.26^{* * *}$ & $8.428^{* * *}$ & $11.55^{* * *}$ & $9.084^{* * *}$ & $9.099^{* * *}$ & $7.834^{* * *}$ & $6.426^{* * *}$ & $4.473^{* * *}$ & $6.650^{* * *}$ & $4.127^{* * *}$ & $12.93 * * *$ & $10.71 * * *$ \\
\hline & $(0.595)$ & (0.609) & $(1.197)$ & $(1.262)$ & $(0.887)$ & $(0.922)$ & $(1.141)$ & $(1.173)$ & $(0.466)$ & $(0.487)$ & $(1.380)$ & $(1.421)$ & $(1.228)$ & $(1.262)$ \\
\hline \multirow[t]{2}{*}{ AGE } & $.64^{* * *}$ & $11.05^{* * *}$ & $11.25^{* * *}$ & $10.83^{* * *}$ & $18.94^{* * *}$ & $19.04^{* * *}$ & $22.26^{* * *}$ & $21.78^{* * *}$ & -0.950 & $-4.001^{* *}$ & $12.69 * * *$ & $12.62^{* * *}$ & $8.713^{* *}$ & $8.318^{* *}$ \\
\hline & (2.033) & $(2.029)$ & $(3.277)$ & $(3.266)$ & $(2.845)$ & $(2.833)$ & $(4.049)$ & $(4.038)$ & $(1.832)$ & $(1.850)$ & $(4.485)$ & $(4.470)$ & $(3.802)$ & $(3.785)$ \\
\hline \multirow[t]{2}{*}{ FEMALE } & $-23.14^{* * *}$ & $-23.43^{* * *}$ & $-31.35^{* * *}$ & $-31.05^{* * *}$ & $-29.11^{* * *}$ & $-29.84^{* * *}$ & $-30.89 * * *$ & $-31.30 * * *$ & $-20.58^{* * *}$ & $-20.90 * * *$ & $-25.83^{* * *}$ & $-26.40 * * *$ & $-21.60^{* * *}$ & $-22.14^{* * *}$ \\
\hline & $(1.156)$ & $(1.154)$ & $(2.004)$ & $(1.974)$ & $(1.722)$ & $(1.708)$ & $(2.282)$ & $(2.278)$ & $(0.923)$ & $(0.922)$ & $(2.728)$ & $(2.708)$ & $(2.227)$ & $(2.217)$ \\
\hline \multirow[t]{2}{*}{ REPEAT } & $-41.47^{* * *}$ & $-38.88^{* * *}$ & $-49.26^{* * *}$ & $-46.08^{* * *}$ & $-35.43^{* * *}$ & $-33.98^{* * *}$ & $-36.98^{* * *}$ & $-34.92^{* * *}$ & $-42.01^{* * *}$ & $-35.32^{* * *}$ & $-39.60^{* * *}$ & $-38.21^{* * *}$ & $-64.62^{* * *}$ & $-58.15^{* * *}$ \\
\hline & (1.303) & $(1.331)$ & $(2.512)$ & $(2.553)$ & $(1.739)$ & $(1.755)$ & $(2.701)$ & $(2.738)$ & $(1.771)$ & (1.894) & $(3.092)$ & $(3.111)$ & $(3.143)$ & $(3.441)$ \\
\hline \multirow[t]{2}{*}{ DISCLIMA } & $982^{* * *}$ & $6.051^{* * *}$ & 0.390 & 0.337 & $7.505^{* * *}$ & $7.589^{* * *}$ & $4.989^{* * *}$ & $5.149 * * *$ & $7.688^{* * *}$ & $7.813^{* * *}$ & $6.271^{* * *}$ & $6.600^{* * *}$ & $7.061^{* * *}$ & $7.235^{* * *}$ \\
\hline & $(0.651)$ & $(0.648)$ & $(1.104)$ & $(1.088)$ & (1.012) & $(1.005)$ & $(1.381)$ & $(1.374)$ & $(0.531)$ & $(0.528)$ & $(1.671)$ & (1.663) & (1.190) & (1.181) \\
\hline \multirow[t]{2}{*}{ PROPQUAL } & 10.61 & 9.149 & $46.68^{* * *}$ & 9.672 & 10.43 & 6.998 & -0.191 & -13.97 & 0.356 & 0.493 & -9.131 & -9.956 & 6.112 & 8.738 \\
\hline & $(6.881)$ & $(5.974)$ & (16.89) & $(12.22)$ & (9.710) & $(7.977)$ & $(12.40)$ & (11.10) & $(4.862)$ & $(4.265)$ & (11.51) & $(8.810)$ & $(25.03)$ & (21.44) \\
\hline \multirow[t]{2}{*}{ TCSHORT } & -0.932 & 0.387 & -3.052 & -2.540 & 1.101 & -0.0143 & 2.328 & 0.160 & -0.718 & -0.209 & 2.650 & 2.565 & -0.820 & 2.958 \\
\hline & (1.536) & (1.339) & $(2.447)$ & (1.718) & $(1.656)$ & $(1.361)$ & $(3.348)$ & $(2.921)$ & $(1.216)$ & $(1.067)$ & $(4.248)$ & (3.237) & (2.530) & $(2.157)$ \\
\hline \multirow[t]{2}{*}{ STRATIO } & $-0.342^{* * *}$ & $-0.293 * * *$ & $-0.764^{* *}$ & 0.0324 & $-0.640 * * *$ & $-0.490 * * *$ & 0.273 & 0.332 & $0.184^{* * *}$ & 0.0309 & -0.00452 & -0.276 & -0.0460 & 0.0413 \\
\hline & $(0.0980)$ & $(0.0855)$ & $(0.357)$ & $(0.280)$ & $(0.206)$ & $(0.171)$ & $(0.318)$ & $(0.280)$ & $(0.0578)$ & $(0.0514)$ & $(0.442)$ & $(0.338)$ & $(0.353)$ & $(0.297)$ \\
\hline \multirow[t]{2}{*}{ SCMATEDU } & $8.132^{* * *}$ & $4.497 * * *$ & $8.836^{* * *}$ & -0.493 & $6.701^{* * *}$ & 1.606 & $11.29^{* * *}$ & $5.639^{* *}$ & $9.700 * * *$ & $3.906^{* * *}$ & $12.42^{* * *}$ & $5.360^{*}$ & $4.993^{* *}$ & $4.223^{*}$ \\
\hline & $(1.655)$ & $(1.462)$ & $(3.132)$ & $(2.294)$ & $(2.025)$ & $(1.710)$ & $(2.605)$ & $(2.418)$ & $(1.157)$ & $(1.075)$ & $(3.691)$ & $(2.908)$ & $(2.538)$ & $(2.162)$ \\
\hline \multirow[t]{2}{*}{ RESPRES } & $20.54^{* * *}$ & $7.703^{* * *}$ & $15.82^{* * *}$ & 2.188 & $8.679 * * *$ & 1.365 & $8.099^{* *}$ & -1.456 & $4.156^{* * *}$ & $-4.127^{* * *}$ & $13.58^{* * *}$ & 2.576 & $18.14^{* * *}$ & -3.655 \\
\hline & (1.914) & (1.931) & (2.373) & $(1.873)$ & (2.139) & (1.905) & $(3.455)$ & (3.455) & (1.429) & $(1.352)$ & $(3.126)$ & (2.653) & $(3.814)$ & $(3.965)$ \\
\hline \multirow[t]{2}{*}{ MESCS } & & $22.95^{* * *}$ & & $32.21 * * *$ & & $28.32 * * *$ & & $17.98^{* * *}$ & & $20.71^{* * *}$ & & $42.34^{* * *}$ & & $33.63^{* * *}$ \\
\hline & & (2.490) & & $(3.085)$ & & (2.948) & & $(4.821)$ & & (1.550) & & (5.144) & & (4.703) \\
\hline \multirow[t]{2}{*}{ MREPEAT } & & $-42.42^{* * *}$ & & $-54.81^{* * *}$ & & $-33.54 * * *$ & & $-47.55^{* * *}$ & & $-39.96 * * *$ & & 6.455 & & -9.597 \\
\hline & & $(5.670)$ & & $(11.12)$ & & $(9.974)$ & & (13.98) & & $(5.074)$ & & (21.34) & & $(7.887)$ \\
\hline \multirow[t]{2}{*}{ _cons } & $252.9^{* * *}$ & $298.5^{* * *}$ & $255.8^{* * *}$ & $308.3^{* * *}$ & $145.8^{* * *}$ & $179.1^{* * *}$ & 104.2 & $143.7^{* *}$ & $459.4^{* * *}$ & $529.6^{* * *}$ & $217.0^{* * *}$ & $267.0^{* * *}$ & $329.8^{* * *}$ & $353.2^{* * *}$ \\
\hline & $(32.86)$ & $(32.80)$ & $(54.34)$ & $(53.02)$ & (46.38) & $(45.94)$ & (65.03) & (64.89) & $(29.15)$ & (29.49) & $(72.31)$ & $(71.70)$ & $(60.41)$ & $(60.09)$ \\
\hline $\mathrm{N}$ & 9141 & 9141 & 4007 & 4007 & 4698 & 4698 & 1849 & 1849 & 16626 & 16626 & 2109 & 2109 & 3232 & 3232 \\
\hline AIC & 99752.1 & 99580.4 & 44235.4 & 44097.2 & 51299.3 & 51185.6 & 19713.0 & 19679.0 & 183854.4 & 183585.0 & 23300.8 & 23234.2 & 36013.0 & 35946.0 \\
\hline BIC & 99844.7 & 99687.2 & 44317.3 & 44191.6 & 51383.2 & 51282.4 & 19784.8 & 19761.9 & 183954.8 & 183700.8 & 23374.3 & 23319.0 & 36092.0 & 36037.2 \\
\hline
\end{tabular}

Notes: Robust standard errors between brackets. w/o p.e. and w/ p.e. stand for without and with peer effect, respectively. ${ }^{*} p<0.1,{ }^{* *} p<0.05,{ }^{* * *} p<0.01$.

$\mathrm{N}=$ Number of observations, AIC $=$ Akaike Information Criterion, BIC $=$ Bayesian Information Criterion, and LR $=$ Log-likelihood Ratio $\chi^{2}$ statistic. 
Table 4

Estimation results - PISA 2015 (Science).

\begin{tabular}{|c|c|c|c|c|c|c|c|c|c|c|c|c|c|c|}
\hline \multirow{2}{*}{ Variables } & \multicolumn{2}{|c|}{ Brazil } & \multicolumn{2}{|c|}{ Chile } & \multicolumn{2}{|c|}{ Colombia } & \multicolumn{2}{|c|}{ Costa Rica } & \multicolumn{2}{|c|}{ Mexico } & \multicolumn{2}{|c|}{ Peru } & \multicolumn{2}{|c|}{ Uruguay } \\
\hline & w/o p.e. & w/ p.e. & w/o p.e. & w/ p.e. & w/o p.e. & w/ p.e. & w/o p.e. & w/ p.e. & w/o p.e. & w/ p.e. & w/o p.e. & w/ p.e. & w/o p.e. & w/ p.e. \\
\hline ESCS & $\begin{array}{l}9.801^{* * *} \\
(0.710)\end{array}$ & $\begin{array}{l}8.060^{* * *} \\
(0.733)\end{array}$ & $\begin{array}{l}12.38^{* * *} \\
(1.098)\end{array}$ & $\begin{array}{l}9.140^{* * *} \\
(1.149)\end{array}$ & $\begin{array}{l}9.865^{* * *} \\
(0.813)\end{array}$ & $\begin{array}{l}7.833^{* * *} \\
(0.840)\end{array}$ & $\begin{array}{l}10.36^{* * *} \\
(0.826)\end{array}$ & $\begin{array}{l}8.251^{* * *} \\
(0.856)\end{array}$ & $\begin{array}{l}8.443^{* * *} \\
(0.782)\end{array}$ & $\begin{array}{l}6.901^{* * *} \\
(0.807)\end{array}$ & $\begin{array}{l}12.53^{* * *} \\
(0.870)\end{array}$ & $\begin{array}{l}9.886^{* * *} \\
(0.911)\end{array}$ & $\begin{array}{l}12.03^{* * *} \\
(1.077)\end{array}$ & $\begin{array}{l}10.14^{* * *} \\
(1.111)\end{array}$ \\
\hline AGE & $\begin{array}{l}11.29^{* * *} \\
(2.416)\end{array}$ & $\begin{array}{l}10.54^{* * *} \\
(2.411)\end{array}$ & $\begin{array}{l}18.64^{* * *} \\
(3.006)\end{array}$ & $\begin{array}{l}18.15^{* * *} \\
(2.994)\end{array}$ & $\begin{array}{l}16.16^{* * *} \\
(2.397)\end{array}$ & $\begin{array}{l}16.56^{* * *} \\
(2.392)\end{array}$ & $\begin{array}{l}7.576^{* * *} \\
(2.791)\end{array}$ & $\begin{array}{l}7.005^{* *} \\
(2.782)\end{array}$ & $\begin{array}{l}11.46^{* * *} \\
(3.024)\end{array}$ & $\begin{array}{l}10.21^{* * *} \\
(3.034)\end{array}$ & $\begin{array}{l}14.58^{* * *} \\
(2.607)\end{array}$ & $\begin{array}{l}14.37^{* * *} \\
(2.598)\end{array}$ & $\begin{array}{l}9.752^{* * *} \\
(3.380)\end{array}$ & $\begin{array}{l}9.545^{* * *} \\
(3.372)\end{array}$ \\
\hline FEMALE & $\begin{array}{l}-13.93^{* * *} \\
(1.372)\end{array}$ & $\begin{array}{l}-14.08^{* * *} \\
(1.369)\end{array}$ & $\begin{array}{l}-19.31^{* * *} \\
(1.819)\end{array}$ & $\begin{array}{l}-19.52^{* * *} \\
(1.800)\end{array}$ & $\begin{array}{l}-23.21^{* * *} \\
(1.406)\end{array}$ & $\begin{array}{l}-23.62^{* * *} \\
(1.401)\end{array}$ & $\begin{array}{l}-22.66^{* * *} \\
(1.561)\end{array}$ & $\begin{array}{l}-23.06^{* * *} \\
(1.556)\end{array}$ & $\begin{array}{l}-12.22^{* * *} \\
(1.525)\end{array}$ & $\begin{array}{l}-12.58^{* * *} \\
(1.523)\end{array}$ & $\begin{array}{l}-17.62^{* * *} \\
(1.619)\end{array}$ & $\begin{array}{l}-18.01^{* * *} \\
(1.606)\end{array}$ & $\begin{array}{l}-15.63^{* * *} \\
(1.966)\end{array}$ & $\begin{array}{l}-15.87^{* * *} \\
(1.959)\end{array}$ \\
\hline REPEAT & $\begin{array}{l}-45.42^{* * *} \\
(1.619)\end{array}$ & $\begin{array}{l}-41.97^{* * *} \\
(1.667)\end{array}$ & $\begin{array}{l}-51.58^{* * *} \\
(2.378)\end{array}$ & $\begin{array}{l}-48.58^{* * *} \\
(2.407)\end{array}$ & $\begin{array}{l}-42.65^{* * *} \\
(1.448)\end{array}$ & $\begin{array}{l}-41.74^{* * *} \\
(1.459)\end{array}$ & $\begin{array}{l}-38.94^{* * *} \\
(1.898)\end{array}$ & $\begin{array}{l}-37.51^{* * *} \\
(1.923)\end{array}$ & $\begin{array}{l}-33.75^{* * *} \\
(2.887)\end{array}$ & $\begin{array}{l}-29.01^{* * *} \\
(3.103)\end{array}$ & $\begin{array}{l}-40.55^{* * *} \\
(1.914)\end{array}$ & $\begin{array}{l}-38.69^{* * *} \\
(1.937)\end{array}$ & $\begin{array}{l}-61.10^{* * *} \\
(2.774)\end{array}$ & $\begin{array}{l}-55.41^{* * *} \\
(3.093)\end{array}$ \\
\hline DISCLISCI & $\begin{array}{l}5.567^{* * *} \\
(0.726)\end{array}$ & $\begin{array}{l}5.637^{* * *} \\
(0.723)\end{array}$ & $\begin{array}{l}5.764^{* * *} \\
(1.058)\end{array}$ & $\begin{array}{l}5.976^{* * *} \\
(1.048)\end{array}$ & $\begin{array}{l}5.730^{* * *} \\
(0.785)\end{array}$ & $\begin{array}{l}5.938^{* * *} \\
(0.782)\end{array}$ & $\begin{array}{l}3.763^{* * *} \\
(0.858)\end{array}$ & $\begin{array}{l}3.891^{* * *} \\
(0.852)\end{array}$ & $\begin{array}{l}7.893^{* * *} \\
(0.898)\end{array}$ & $\begin{array}{l}8.044^{* * *} \\
(0.895)\end{array}$ & $\begin{array}{l}4.355^{* * *} \\
(0.909)\end{array}$ & $\begin{array}{l}4.611^{* * *} \\
(0.905)\end{array}$ & $\begin{array}{l}3.815^{* * *} \\
(1.031)\end{array}$ & $\begin{array}{l}3.576^{* * *} \\
(1.027)\end{array}$ \\
\hline PROAT5AM & $\begin{array}{l}83.15^{* * *} \\
(18.39)\end{array}$ & $\begin{array}{l}56.38^{* * *} \\
(15.56)\end{array}$ & $\begin{array}{l}51.83^{*} \\
(26.45)\end{array}$ & $\begin{array}{l}5.936 \\
(18.57)\end{array}$ & $\begin{array}{l}42.39^{* * *} \\
(15.74)\end{array}$ & $\begin{array}{l}11.07 \\
(13.09)\end{array}$ & $\begin{array}{l}8.518 \\
(10.95)\end{array}$ & $\begin{array}{l}-3.040 \\
(8.379)\end{array}$ & $\begin{array}{l}33.67^{* * *} \\
(10.58)\end{array}$ & $\begin{array}{l}33.91^{* * *} \\
(9.164)\end{array}$ & $\begin{array}{l}8.539 \\
(13.37)\end{array}$ & $\begin{array}{l}1.934 \\
(10.41)\end{array}$ & $\begin{array}{l}244.1^{* * *} \\
(62.66)\end{array}$ & $\begin{array}{l}128.9^{* *} \\
(57.21)\end{array}$ \\
\hline STAFFSHORT & $\begin{array}{l}-3.911^{* *} \\
(1.532)\end{array}$ & $\begin{array}{l}-3.435^{* * *} \\
(1.325)\end{array}$ & $\begin{array}{l}-2.325 \\
(3.105)\end{array}$ & $\begin{array}{l}-1.674 \\
(2.164)\end{array}$ & $\begin{array}{c}-0.0561 \\
(1.641)\end{array}$ & $\begin{array}{l}0.471 \\
(1.351)\end{array}$ & $\begin{array}{l}1.609 \\
(1.473)\end{array}$ & $\begin{array}{l}0.914 \\
(1.124)\end{array}$ & $\begin{array}{l}-1.160 \\
(2.201)\end{array}$ & $\begin{array}{l}0.609 \\
(1.897)\end{array}$ & $\begin{array}{l}-2.346 \\
(1.956)\end{array}$ & $\begin{array}{l}-0.224 \\
(1.537)\end{array}$ & $\begin{array}{l}-2.211 \\
(1.682)\end{array}$ & $\begin{array}{l}-0.793 \\
(1.505)\end{array}$ \\
\hline STRATIO & $\begin{array}{l}-0.236^{* * *} \\
(0.0882)\end{array}$ & $\begin{array}{l}-0.147^{*} \\
(0.0753)\end{array}$ & $\begin{array}{l}0.0157 \\
(0.390)\end{array}$ & $\begin{array}{l}0.636^{* *} \\
(0.290)\end{array}$ & $\begin{array}{l}-0.376^{* * *} \\
(0.129)\end{array}$ & $\begin{array}{c}-0.0821 \\
(0.110)\end{array}$ & $\begin{array}{r}-0.0775 \\
(0.194)\end{array}$ & $\begin{array}{c}-0.0513 \\
(0.147)\end{array}$ & $\begin{array}{l}0.137 \\
(0.139)\end{array}$ & $\begin{array}{l}0.0300 \\
(0.120)\end{array}$ & $\begin{array}{l}0.232 \\
(0.193)\end{array}$ & $\begin{array}{l}0.0962 \\
(0.153)\end{array}$ & $\begin{array}{l}0.153 \\
(0.176)\end{array}$ & $\begin{array}{l}0.0965 \\
(0.155)\end{array}$ \\
\hline SCIERES & $\begin{array}{l}4.831^{* * *} \\
(0.746)\end{array}$ & $\begin{array}{l}2.518^{* * *} \\
(0.653)\end{array}$ & $\begin{array}{l}5.407^{* * *} \\
(1.152)\end{array}$ & $\begin{array}{l}1.905^{* *} \\
(0.830)\end{array}$ & $\begin{array}{l}3.342^{* * *} \\
(0.950)\end{array}$ & $\begin{array}{l}0.705 \\
(0.809)\end{array}$ & $\begin{array}{l}0.278 \\
(1.124)\end{array}$ & $\begin{array}{l}-0.136 \\
(0.860)\end{array}$ & $\begin{array}{l}4.840^{* * *} \\
(0.829)\end{array}$ & $\begin{array}{l}1.657^{* *} \\
(0.775)\end{array}$ & $\begin{array}{l}4.185^{* * *} \\
(0.987)\end{array}$ & $\begin{array}{l}0.514 \\
(0.809)\end{array}$ & $\begin{array}{l}1.903^{*} \\
(1.009)\end{array}$ & $\begin{array}{l}0.736 \\
(0.911)\end{array}$ \\
\hline RESPRES & $\begin{array}{l}13.99^{* * *} \\
(1.993)\end{array}$ & $\begin{array}{l}4.312^{* *} \\
(1.867)\end{array}$ & $\begin{array}{l}10.55^{* * *} \\
(2.318)\end{array}$ & $\begin{array}{l}-0.427 \\
(1.761)\end{array}$ & $\begin{array}{l}9.514^{* * *} \\
(1.674)\end{array}$ & $\begin{array}{l}1.136 \\
(1.562)\end{array}$ & $\begin{array}{l}-1.592 \\
(2.889)\end{array}$ & $\begin{array}{l}0.886 \\
(2.228)\end{array}$ & $\begin{array}{l}3.079 \\
(2.315)\end{array}$ & $\begin{array}{l}-4.045^{*} \\
(2.131)\end{array}$ & $\begin{array}{l}6.768^{* * *} \\
(1.558)\end{array}$ & $\begin{array}{l}-0.963 \\
(1.387)\end{array}$ & $\begin{array}{l}17.34^{* * *} \\
(3.049)\end{array}$ & $\begin{array}{l}2.981 \\
(3.273)\end{array}$ \\
\hline MESCS & & $\begin{array}{l}23.50^{* * *} \\
(2.548)\end{array}$ & & $\begin{array}{l}28.26^{* * *} \\
(3.175)\end{array}$ & & $\begin{array}{l}30.06^{* * *} \\
(2.967)\end{array}$ & & $\begin{array}{l}25.95^{* * *} \\
(2.796)\end{array}$ & & $\begin{array}{l}22.81^{* * *} \\
(2.810)\end{array}$ & & $\begin{array}{l}26.35^{* * *} \\
(2.762)\end{array}$ & & $\begin{array}{l}25.62^{* * *} \\
(4.157)\end{array}$ \\
\hline MREPEAT & & $\begin{array}{l}-44.29^{* * *} \\
(6.096)\end{array}$ & & $\begin{array}{l}-68.14^{* * *} \\
(12.30)\end{array}$ & & $\begin{array}{l}-23.83^{* *} \\
(9.436)\end{array}$ & & $\begin{array}{l}-20.24^{* *} \\
(8.959)\end{array}$ & & $\begin{array}{l}-28.32^{* * *} \\
(7.721)\end{array}$ & & $\begin{array}{l}-30.41^{* * *} \\
(10.10)\end{array}$ & & $\begin{array}{l}-11.32^{*} \\
(6.727)\end{array}$ \\
\hline - cons & $\begin{array}{l}258.4^{* * *} \\
(38.57)\end{array}$ & $\begin{array}{l}308.5^{* * *} \\
(38.60)\end{array}$ & $\begin{array}{l}154.9^{* * *} \\
(48.46)\end{array}$ & $\begin{array}{l}198.4^{* * *} \\
(48.08)\end{array}$ & $\begin{array}{l}201.9^{* * *} \\
(38.42)\end{array}$ & $\begin{array}{l}233.5^{* * *} \\
(38.39)\end{array}$ & $\begin{array}{l}330.5^{* * *} \\
(44.41)\end{array}$ & $\begin{array}{l}369.7^{* * *} \\
(44.33)\end{array}$ & $\begin{array}{l}232.5^{* * *} \\
(47.63)\end{array}$ & $\begin{array}{l}293.1^{* * *} \\
(48.08)\end{array}$ & $\begin{array}{l}181.4^{* * *} \\
(41.66)\end{array}$ & $\begin{array}{l}234.1^{* * *} \\
(41.54)\end{array}$ & $\begin{array}{l}320.6^{* * *} \\
(53.85)\end{array}$ & $\begin{array}{l}346.0^{* * *} \\
(53.69)\end{array}$ \\
\hline $\mathrm{N}$ & 9896 & 9896 & 5474 & 5474 & 8492 & 8492 & 5437 & 5437 & 6147 & 6147 & 5982 & 5982 & 4829 & 4829 \\
\hline AIC & 111853.0 & 111698.3 & 61117.6 & 60978.1 & 94363.0 & 94249.5 & 59573.1 & 59460.0 & 67864.9 & 67789.6 & 65939.4 & 65812.7 & 54401.0 & 54347.3 \\
\hline BIC & 111946.6 & 111806.3 & 61203.5 & 61077.2 & 94454.6 & 94355.2 & 59658.9 & 59559.0 & 67952.3 & 67890.4 & 66026.4 & 65913.2 & 54485.3 & 54444.6 \\
\hline LR & 16 & 5.6 & 14 & 9.8 & & 5.2 & & 3.6 & & 7.4 & 137 & 7.6 & & 5.2 \\
\hline
\end{tabular}

Notes: Robust standard errors between brackets. w/o p.e. and w/ p.e. stand for without and with peer effect, respectively. ${ }^{*} p<0.1,{ }^{* *} p<0.05,{ }^{* * *} p<0.0$

$\mathrm{N}=$ Number of observations, AIC $=$ Akaike Information Criterion, BIC $=$ Bayesian Information Criterion, and LR $=$ Log-likelihood Ratio $\chi^{2}$ statistic. 


\begin{tabular}{|c|c|c|c|c|c|c|c|c|c|c|}
\hline \multirow{2}{*}{ Country } & \multirow{2}{*}{ Effect } & \multicolumn{3}{|c|}{2009 - Reading } & \multicolumn{3}{|c|}{2012 - Mathematics } & \multicolumn{3}{|c|}{2015 - Science } \\
\hline & & Null & w/o p.e. & w/ p.e. & Null & w/o p.e. & w/ p.e. & Null & w/o p.e. & $\mathrm{w} /$ p.e. \\
\hline \multirow{4}{*}{ Brazil } & Within-School & 4531.1 & 3995.9 & 3993.6 & 3309.1 & 2833.2 & 2832.6 & 4829.5 & 4395.5 & 4391.2 \\
\hline & Between-School & 2975.1 & 1312.2 & 860.1 & 2589.2 & 1091.5 & 764.7 & 2763.5 & 881.7 & 569.7 \\
\hline & Overall & 7506.2 & 5308.1 & 4853.6 & 5898.2 & 3924.8 & 3597.2 & 7593.0 & 5277.2 & 4960.9 \\
\hline & $\rho$ & 0.40 & 0.25 & 0.18 & 0.44 & 0.28 & 0.21 & 0.36 & 0.17 & 0.11 \\
\hline \multirow{4}{*}{ Chile } & Within-School & 3983.3 & 3587.7 & 3579.0 & 3790.1 & 3280.6 & 3275.8 & 4269.6 & 3813.1 & 3809.1 \\
\hline & Between-School & 3195.6 & 1112.2 & 472.4 & 4202.3 & 1182.9 & 485.7 & 3774.3 & 1179.0 & 482.5 \\
\hline & Overall & 7178.9 & 4699.9 & 4051.4 & 7992.3 & 4463.5 & 3761.5 & 8043.9 & 4992.1 & 4291.6 \\
\hline & $\rho$ & 0.45 & 0.24 & 0.12 & 0.53 & 0.27 & 0.13 & 0.47 & 0.24 & 0.11 \\
\hline \multirow{4}{*}{ Colombia } & Within-School & 4664.1 & 4111.7 & 4108.8 & 3448.2 & 2893.3 & 2889.5 & 4225.6 & 3667.4 & 3665.0 \\
\hline & Between-School & 2733.7 & 1138.2 & 532.2 & 2030.8 & 891.0 & 535.5 & 1784.3 & 759.5 & 463.9 \\
\hline & Overall & 7397.8 & 5249.9 & 4641.0 & 5479.1 & 3784.4 & 3425.0 & 6009.9 & 4427.0 & 4128.9 \\
\hline & $\rho$ & 0.37 & 0.22 & 0.11 & 0.37 & 0.24 & 0.16 & 0.30 & 0.17 & 0.11 \\
\hline \multirow{4}{*}{ Costa Rica } & Within-School & 3751.5 & 3177.7 & 3175.3 & 2722.6 & 2175.6 & 2173.0 & 3549.0 & 3110.6 & 3105.7 \\
\hline & Between-School & 2296.8 & 866.9 & 549.0 & 1949.2 & 811.2 & 568.6 & 1385.3 & 721.5 & 366.3 \\
\hline & Overall & 6048.3 & 4044.6 & 3724.3 & 4671.8 & 2986.8 & 2741.6 & 4934.3 & 3832.1 & 3472.0 \\
\hline & $\rho$ & 0.38 & 0.21 & 0.15 & 0.42 & 0.27 & 0.21 & 0.28 & 0.19 & 0.11 \\
\hline \multirow{4}{*}{ Mexico } & Within-School & 3527.8 & 3319.9 & 3320.5 & 3570.9 & 3335.9 & 3334.8 & 3570.4 & 3403.9 & 3399.9 \\
\hline & Between-School & 3075.2 & 1387.0 & 836.8 & 1919.1 & 1037.3 & 741.1 & 1581.6 & 685.4 & 456.5 \\
\hline & Overall & 6603.0 & 4707.0 & 4157.3 & 5490.0 & 4373.2 & 4075.9 & 5152.0 & 4089.3 & 3856.4 \\
\hline & $\rho$ & 0.47 & 0.29 & 0.20 & 0.35 & 0.24 & 0.18 & 0.31 & 0.17 & 0.12 \\
\hline \multirow{4}{*}{ Peru } & Within-School & 4525.0 & 4047.6 & 4046.3 & 3635.2 & 3188.9 & 3190.9 & 3710.3 & 3306.7 & 3305.5 \\
\hline & Between-School & 4586.3 & 1437.7 & 728.9 & 3259.3 & 1541.6 & 794.0 & 1985.0 & 769.2 & 402.3 \\
\hline & Overall & 9111.3 & 5485.3 & 4775.3 & 6894.5 & 4730.6 & 3984.9 & 5695.3 & 4075.9 & 3707.8 \\
\hline & $\rho$ & 0.50 & 0.26 & 0.15 & 0.47 & 0.33 & 0.20 & 0.35 & 0.19 & 0.11 \\
\hline \multirow{4}{*}{ Uruguay } & Within-School & 5658.3 & 4821.0 & 4815.7 & 4408.0 & 3702.0 & 3689.4 & 4822.5 & 4302.5 & 4296.9 \\
\hline & Between-School & 3721.1 & 805.4 & 523.8 & 3082.7 & 737.3 & 451.5 & 2540.6 & 505.7 & 350.9 \\
\hline & Overall & 9379.4 & 5626.4 & 5339.5 & 7490.7 & 4439.3 & 4140.9 & 7363.1 & 4808.2 & 4647.7 \\
\hline & $\rho$ & 0.40 & 0.14 & 0.10 & 0.41 & 0.17 & 0.11 & 0.35 & 0.11 & 0.08 \\
\hline
\end{tabular}

Note: Null is a naive benchmark model whose specification includes only a constant term. w/o p.e. and w/ p.e. stand for without and with peer effect, respectively. 
It is noticeable from the empirical results that the preferred model is the one which includes the peer effect variables. The variables MESCS and MREPEAT are statistically significant for all countries on all PISA editions. Some coefficients associated to school group, which are significant in the model without peer effect, become not significant when peer effect is taken into account. In the sense of Hanchane and Mostafa (2012), this result suggests an endogeineity problem, so the variables MESCS and MREPEAT should be included in the model. The Log-likelihood Ratio (LR) test also suggests that the preferred model is the one including peer effects variables.

Additionally, one can highlight that the positive value for the coefficient of MESCS indicates that the higher the socioeconomic status of the school community the higher the student performance. That is, if the student is located in a school where the cultural and socioeconomic status of the community surrounding him is high, the chances of a good performance in the PISA assessment increase. In the same way, MREPEAT presents a negative coefficient which indicates that the higher the retention rate in the school, the lower the student performance. In brief, exposing the student to a better environment (high cultural and socioeconomic levels community and "better" peers within the school) improves the student performance. These peer-effect findings suggest that the socioeconomic segmentation is very present in Latin American educational systems, and possibly reinforcing the inequalities that already exist in society itself.

The discussion that follows is based only on the model with peer effects since this is the preferred according to the tests.

\subsection{School Effect}

First, it is necessary to evaluate the school effects results. Figure 3 shows the intraclass correlation $\rho$ for the specification with and without peer effects, and the null model. For the null model, the school effect is high for all Latin American countries $-\rho$ is around 0.4. This result suggests that, on average, $40 \%$ of the student performance in such countries is explained by differences among schools. Chile presents the highest values for Mathematics and Science while Peru has the highest value for Reading. The lowest values, around 0.3, are found in Colombia (Reading), Costa Rica (Science), and Mexico (Mathematics).

Hanchane and Mostafa (2012) found that the school effect is around 7\% for Finland and UK, and, it is around $20 \%$ in Germany. Although the results cannot be directly compared, Brunner et al. (2018) found that, overall, Finland, Iceland, Norway, Sweden and Denmark have a school effect of less than 15\%, and Latin American countries have values above $30 \%$.

When the explanatory variables are included, i.e., taking into account student characteristics, family background and the school facilities - in the model without peer effect - there is an average reduction of $45 \%$ in the size of the school effect. The largest reduction is observed for Uruguay, with a fall of around $60 \%$ of the effect in the three areas of knowledge. The lowest reduction pointed out by the models without peer effects is around $30 \%$ for Mexico and Peru in Mathematics, and Costa Rica in Science.

Lastly, when the peer effect is included, an additional reduction of the school effect of $1 / 3$, on average, is observed. Chile presented the largest reduction for all three areas (around 1/2), and Peru and Colombia presented similar results for Mathematics and Reading, respectively. 


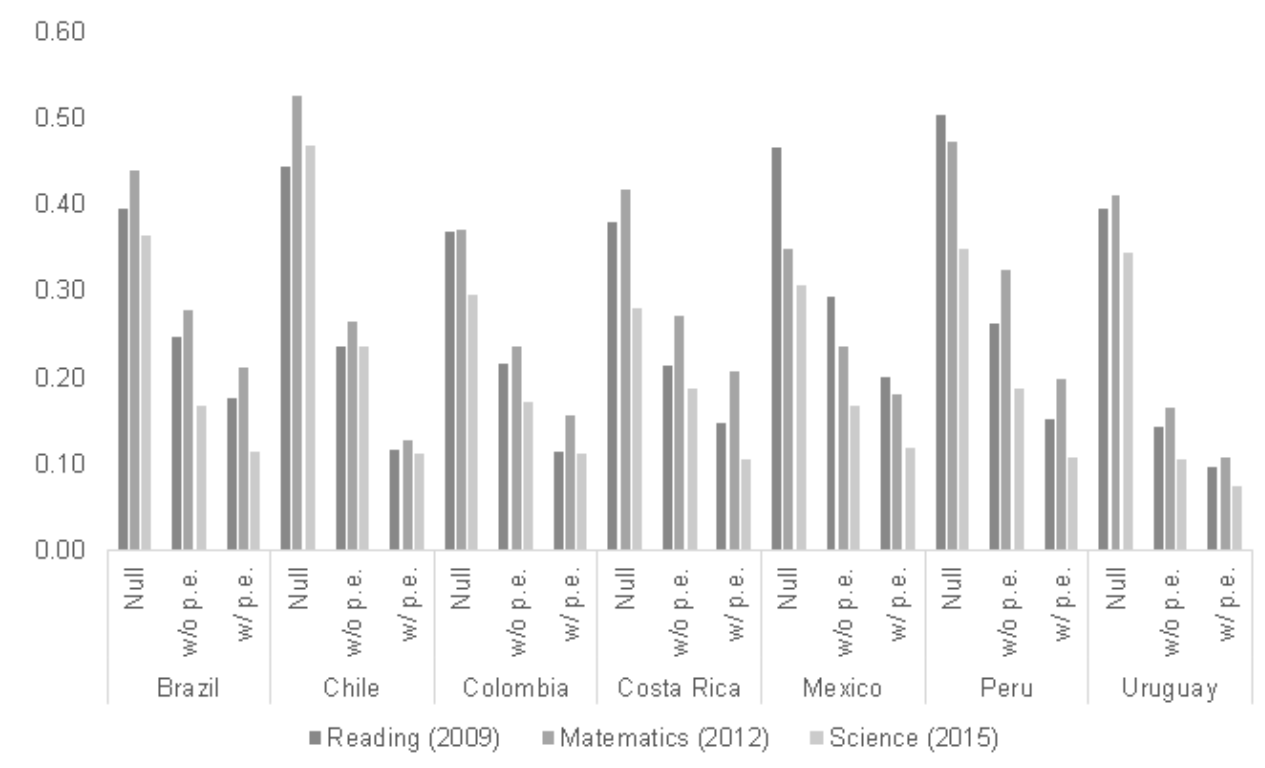

Note: Null is a naive benchmark model whose specification includes only a constant term. w/o p.e. and w/ p.e. stand for without and with peer effect, respectively.

Figure 3. Intraclass Correlation $(\rho)$.

It is worth to mention that, even taking into consideration student factors (individual, family background and school facility) and also peer effects, the school effect is not negligible for Latin American countries. For Brazil, Costa Rica, Mexico, and Peru, the effect is above $20 \%$ for some areas, while Uruguay presented the lowest values (around 10\%).

So far, these results point out to the existence of a certain degree of stratification among schools in Latin America, i.e., there is a significant difference among schools. This difference is quite relevant in determining the student performance.

\subsection{Student Performance}

Considering the three domains of PISA assessment, it can be observed that family background (ESCS) is statistically significant for all countries and positively related to the students' performance. In brief, the estimated effect is positive, i.e., the higher the socioeconomic level and family culture, the better the student's result. The lowest observed effect was for the Peruvian students in the area of mathematics (4.127), while the largest observed effect was for the Uruguayan students in the reading area (13.69).

Concerning the students' individual characteristics, the results for gender gap point out that girls outperform boys in Reading, while boys perform better than girls in Science and Mathematics. Overall, the largest gender difference is found in Mathematics. In Reading and Science, differences are similar. In Reading, the biggest difference between boys and girls occurred for Uruguay (29.47) and Brazil (22.68), in Mathematics for Costa Rica (-31.30) and Chile (-31.05), and in Sciences for Colombia (-23.62) and to Costa Rica (-23.06).

Regarding age, even with an small age variation explored in PISA (between 15 years and 
3 months and 16 years and 2 months), it is found a positive effect on student achievement. In reading, the greatest significant effect occurred for Costa Rica (16.14) and the lowest effect occurred for Peru (6.889), while for Mexican students this variable had no relevance. The effects estimated for the age variable in mathematics were larger than the observed for the reading area, with the greatest effects occurring for Costa Rica and Colombia. It is interesting to observe that for Mexico, contrary to the results of other countries, the effect was negative, but very small. For Science, the effect of age was significant and positive for all countries, with estimated coefficients ranging from 7.005 for Costa Rica to 18.15 for Chile.

Grade retention (REPEAT) is negative and statistically significant for all model in all countries. This finding suggests that if the student repeats an academic year at least once, he tends to have worse performance than the others do. For the reading area, the estimated coefficient ranged from -57.62 for Uruguay to -37.33 for Mexico. In mathematics, the variation was -58.15 for Uruguay and -33.98 for Colombia and in Science of -55.41 for Uruguay and -29.01 for Mexico. It is worth to notice that Uruguay, the country which repetition taxes had the biggest negative effect on the student results, also has high failure rates, with $23.0 \%$ for Lower secondary and $40.8 \%$ for Upper secondary. ${ }^{5}$

Other students' characteristics were included in some model specifications. For example, the enthusiasm for the subject under assessment (2009 and 2015) and the student level of dedication/perseverance (2012) were found positive and statistically significant for all countries. However, these results are not present here due to the high loss of observation in the sample. For 2012, for example, the models with the largest number of explanatory variables had the participation of less than $30 \%$ of the sample.

In relation to school facilities factors, it is worthy to highlight the variables perception of the student about disciplinary climate in the classroom (DISCLIMA and DISCLICI), and educational resource availability (SCMATEDU and SCIERES). The former is found to be positive and statistically significant for all countries, i.e., the better the disciplinary environment in the classroom the higher the student performance on PISA assessment. These indicators intend to measure the students and teacher behavior and interaction in the classroom. If there is too much "noise" due to student misbehavior and the teacher fails to control it, the learning processes are negatively impacted and the student is expected to perform worse. This effect is systematically significant for all seven countries in the areas of reading and science. For math, only Chile has no significant effect. In reading, the greatest effect is observed for Peru (12.51), followed by Colombia (9.206), and the lowest for Chile and Uruguay (about 2.5). For mathematics, disregarding Chile that did not have significant effect, it is observed that the estimated coefficients is closer, ranging from 5.149 for Costa Rica and 7.813 for Mexico. In the area of Sciences, the greatest effect occurred for Mexico with an estimated coefficient of 8.044 and the lowest for Uruguay (3.756).

The variable educational resource availability (SCMATEDU and SCIERES) is also positive and significant for almost all countries. This result suggests that increasing educational resource availability may improve the student performance. This evidence is larger for the Reading and

\footnotetext{
${ }^{5}$ http://edu.mercosur.int/pt-BR/estatisticas/viewcategory/1328-indicadores-educacionais-mercosur.html.
} 
Mathematics areas, where the index of teaching resources is significant for five of the seven Latin American countries considered. In the area of Sciences, the effect is significant for only three countries. However, it should be noted that, differently of Math and Reading, the indicator of resources availability for Sciences may be fragile and biased, since the components of the indicator only subjectively assess the level of adequacy of available resources. The data are obtained from the principal's opinion about the situation of his school in relation to others that he may have as a reference.

A surprising result is found for the teachers' educational degree. For the PISA editions of 2009 and 2012, the percentage of teachers with higher education (PROQUAL) is included in the model. This variable is the proportion of teachers in the school who have an ISCED (International Standard Classification of Education) 5A qualification, i.e, teachers with Bachelor, Master or equivalent degree. This variable is not significant for any countries, which suggests that whether a teacher has a higher education or not is irrelevant in determining the student performance.

PISA 2015 models contemplate the percentage of teachers with Master degree or equivalent (PROAT5AM). In this case, this variable is positive and significant for Brazil, Mexico and Uruguay, i.e., the larger the percentage of teachers with Master degree or equivalent the higher the student performance in Science for these countries.

Three variables related to the administration of the school resources are also included: the student-to-teacher ratio (STRATIO); an index of teachers - TCSHORT for the PISA editions of 2009 and 2012 - or teaching staff (teachers plus assistants) - STAFFSHORT for PISA edition of 2015 - shortage; and an index for management autonomy of the school in allocating the available resources. The coefficient for STRATIO is negative and statistically significant for Brazil (all three subjects) and Colombia (Mathematics); TCSHORT (2009/2012) is not significant for all countries but STAFFSHORT (2015) is negative and significant only for Brazil. And RESPRES is positive and significant only for Brazil (all three subjects). These results suggest that the school administration in Brazil has a significant impact on the student performance. This impact is twofold: the lack of staff in the school and the rigidity and difficulty in managing the available school resources diminish the performance of Brazilian students. It is worthy to notice that this finding seems to be important only for Brazil.

\section{Final Remarks}

In order to assess the determinants of the Latin American students' performance, the multilevel approach is used on the last three PISA editions (2009, 2012 and 2015) data. The proposed procedure allowed us to point out, in general, that

1. The students' individual characteristics and family background;

2. The disciplinary climate in the classroom and educational resources availability;

3. The socioeconomic status of the school and the performance of those surrounding the student (the peer effect), and

4. The differences among the schools (the school effect)

\section{(6) PUCP}


are the main determinants of the Latin American students performance on PISA.

These determinants are in line with the literature mentioned throughout this paper. The first of them is the most commonly found in the EER literature. It suggests that the better the background and the socioeconomic status of the student's family better is its performance on PISA, which is quite important in determining the student's profile.

The second determinant stands for the educational resources availability and student's perception of the environment in the school and in the classroom. The former is related to the physical resources the students have access in the school. More resource availability is better for the students' performance. The later it is mostly related to the student's interaction with the teacher and other students, the noise, disorder, and whether the student can work in the school/classroom, and the student's difficulty in understand what the teacher says. Our results indicates that the better the students' perception of the school/classroom environment, the better the students' performance.

The importance of the last two points is worthy of recognition: the cultural and socioeconomic status of the school community and the difference among the schools per se are of paramount importance in determining the student performance. This result suggests that the better the environment surrounding the student the better his performance in PISA. That is, the socioeconomic status of the neighborhood where the school is located is relevant. Additionally, the differences among the neighborhoods is important as well. This seems to make sense since inequality is very high in Latin American countries.

It is worth to highlight a specific result for Brazil: the school administration is significant in influencing the student performance. This finding can be explained by the difficulties that the school manager has in allocating efficiently the available resources, which includes both teachers and staff personnel, and educational materials. These difficulties are found in public schools mostly, since government-managed schools have almost no administrative autonomy in Brazil.

Lastly, an implication of our results suggests that if Latin American countries governments intend to improve their students' performance, they should direct their policies to the schools and communities in disadvantages. Thus, they should give preference for policies that improve the school and the environment surrounding it, consequently, reducing the inequality in the country. 


\section{References}

Brunner, M., Keller, U., Wenger, M., Fischbach, A., and Lüdtke, O. (2018). Between-School Variation in Students' Achievement, Motivation, Affect, and Learning Strategies: Results from 81 Countries for Planning Group-Randomized Trials in Education. Journal of Research on Educational Effectiveness 11 (3), 452-478.

Caldas, S. J., and Bankston, C. (1997). Effect of School Population Socioeconomic Status on Individual Academic Achievement. The Journal of Educational Research 90 (5), 269-277.

Coleman, J. S., Campbell, E. Q., Hobson, C. J., McPartland, F., Mood, A. M., and Weinfeld, F. D. (1966). Equality of educational opportunity. Washington, DC: U.S. Government Printing Office.

de Jorge-Moreno, J. (2016). Factores explicativos del rendimiento escolar en Latinoamérica con datos PISA 2009. Revista de Métodos Cuantitativos para la Economía y la Empresa 22, 216-229.

De Leeuw, J., Meijer, E., and Goldstein, H. (2008). Handbook of multilevel analysis. Springer.

Dewey, J., Husted, T. A., and Kenny, L. W. (2000). The ineffectiveness of school inputs: a product of misspecification? Economics of Education Review 19 (1), 27-45.

Greenwald, R., Hedges, L. V., and Laine, R. D. (1996a). The Effect of School Resources on Student Achievement. Review of Educational Research 66 (3), 361-396.

Greenwald, R., Hedges, L. V., and Laine, R. D. (1996b). Interpreting Research on School Resources and Student Achievement: A Rejoinder to Hanushek. Review of Educational Research 66 (3), 411-416.

Hanchane, S., and Mostafa, T. (2012). Solving endogeneity problems in multilevel estimation: an example using education production functions. Journal of Applied Statistics 39(5), 1101-1114.

Hanushek, E. A., Jamison, D. T., Jamison, E. A., and Woessmann, L. (2008). Education and Economic Growth: It's Not Just Going to School, but Learning Something While There That Matters. Education Next 8(2), 62-70.

Hanushek, E. A., Peterson, P. E., and Woessmann, L. (2012). Achievement Growth: International and US State Trends in Student Performance. Program on Education Policy and Governance, Harvard University.

Hanushek, E. A., Rivkin, S. G., and Taylor, L. L. (1996). Aggregation and the Estimated Effects of School Resources. The Review of Economics and Statistics 78 (4), 611-627.

Hanushek, E. A., and Woessmann, L. (2012). Do better schools lead to more growth? Cognitive skills, economic outcomes, and causation. Journal of Economic Growth 17(4), 267-321.

Hedges, L. V., Laine, R. D., and Greenwald, R. (1994). An Exchange: Part I: Does Money Matter? A Meta-Analysis of Studies of the Effects of Differential School Inputs on Student Outcomes. Educational Researcher $23(3), 5-14$.

Ho, E. S. C. (2013). Multilevel analysis of the PISA Data: Insights for policy and practice. The Chinese University of Hong Kong Press.

Hopfenbeck, T. N., Lenkeit, J., Masri, Y. E., Cantrell, K., Ryan, J., and Baird, J. (2018). Lessons 
Learned from PISA: A Systematic Review of Peer-Reviewed Articles on the Programme for International Student Assessment. Scandinavian Journal of Educational Research 62 (3), 333-353.

Lindorff, A., Sammons, P. M., and Hall, J. (2020). International Perspectives in Educational Effectiveness Research: A Historical Overview. In J. Hall, A. Lindorff, and P. Sammons (Eds.), International Perspectives in Educational Effectiveness Research (pp. 9-31). Springer, Cham.

OECD (2009). PISA Data Analysis Manual: SPSS, Second Edition. OECD Publishing.

OECD (2012). PISA 2009 Technical Report. OECD Publishing, Paris.

OECD (2014). PISA 2012 Technical Background. OECD Publishing, Paris.

OECD (2017). PISA 2015 Technical Background. OECD Publishing, Paris.

OECD (2020). Education at a Glance 2020. OECD Publishing, Paris.

Rasbash, J., Steele, F., Browne, W., and Goldstein, H. (2017). A User's Guide to MLwiN, v3.00. Centre for Multilevel Modelling, University of Bristol.

Reynolds, D., Sammons, P., Fraine, B. D., Damme, J. V., Townsend, T., Teddlie, C., and Stringfield, S. (2014). Educational effectiveness research (EER): a state-of-the-art review. School Effectiveness and School Improvement 25 (2), 197-230.

van Ewijk, R., and Sleegers, P. (2010). The effect of peer socioeconomic status on student achievement: A meta-analysis. Educational Research Review 5(2), 134-150.

Yalcin, S. (2017). Determining the Relationships between Selected Variables and Latent Classes in Students' PISA Achievement. International Journal of Research in Education and Science 3(2), 589-603. 